\title{
Discovery and Prevalence of Divergent RNA Viruses in European Field Voles and Rabbits
}

\author{
Theocharis Tsoleridis ${ }^{1,2, *(\mathbb{D})}$, Joseph G. Chappell ${ }^{1,2}$, Elodie Monchatre-Leroy ${ }^{3}{ }^{\mathbb{C}}$, \\ Gérald Umhang ${ }^{3}$, Mang Shi ${ }^{4}$, Malcolm Bennett ${ }^{5}$, Rachael E. Tarlinton ${ }^{5} \mathbb{D}$, \\ C. Patrick McClure 1,2 ${ }^{1}$, Edward C. Holmes 4 (D) and Jonathan K. Ball 1,2,* \\ 1 School of Life Sciences, The University of Nottingham, Nottingham NG7 2UH, UK; \\ joseph.chappell@nottingham.ac.uk (J.G.C.); patrick.mcclure@nottingham.ac.uk (C.P.M.) \\ 2 Wolfson Centre for Global Virus Infections, The University of Nottingham, Nottingham NG7 2UH, UK \\ 3 Anses, Laboratoire de la Rage et de la Faune Sauvage, 54220 Malzeville, France; \\ elodie.monchatre-leroy@anses.fr (E.M.-L.); gerald.umhang@anses.fr (G.U.) \\ 4 Marie Bashir Institute for Infectious Diseases and Biosecurity, School of Life and Environmental Sciences and \\ School of Medical Sciences, The University of Sydney, Sydney, NSW 2006, Australia; \\ mang.shi@sydney.edu.au (M.S.); edward.holmes@sydney.edu.au (E.C.H.) \\ 5 School of Veterinary Medicine and Science, University of Nottingham, Sutton Bonington Campus, \\ Loughborough LE12 5RD, UK; m.bennett@nottingham.ac.uk (M.B.); \\ rachael.tarlinton@nottingham.ac.uk (R.E.T.) \\ * Correspondence: t.tsoleridis@nottingham.ac.uk (T.T.); jonathan.ball@nottingham.ac.uk (J.K.B.)
}

Received: 16 December 2019; Accepted: 27 December 2019; Published: 31 December 2019

\begin{abstract}
The advent of unbiased metagenomic virus discovery has revolutionized studies of virus biodiversity and evolution. Despite this, our knowledge of the virosphere, including in mammalian species, remains limited. We used unbiased metagenomic sequencing to identify RNA viruses in European field voles and rabbits. Accordingly, we identified a number of novel RNA viruses including astrovirus, rotavirus A, picorna-like virus and a narmovirus (paramyxovirus). In addition, we identified a sobemovirus and a novel luteovirus that likely originated from the rabbit diet. These newly discovered viruses were often divergent from those previously described. The novel astrovirus was most closely related to a virus sampled from the rodent-eating European roller bird (Coracias garrulous). PCR screening revealed that the novel narmovirus in the UK field vole had a prevalence of approximately $4 \%$, and shared common ancestry with other rodent narmoviruses sampled globally. Two novel rotavirus A sequences were detected in a UK field vole and a French rabbit, the latter with a prevalence of $5 \%$. Finally, a highly divergent picorna-like virus found in the gut of the French rabbit virus was only $\sim 35 \%$ similar to an arilivirus at the amino acid level, suggesting the presence of a novel viral genus within the Picornaviridae.
\end{abstract}

Keywords: virus discovery; paramyxovirus; rotavirus A; astrovirus; picorna-like virus; rodents; rabbits; field voles

\section{Introduction}

RNA viruses likely infect every species of cellular life [1]. However, due to their potential and sometimes profound impact on public health and the agricultural industries, most attention has understandably been directed toward those viruses that affect humans and economically important animals and plants. Hence, our knowledge of the diversity, evolution and functional biology of RNA viruses infecting a wider range of host species is limited. This major sampling bias has been in part addressed by recent studies reporting the discovery of a multitude of new invertebrates and vertebrate 
viruses, massively increasing the known virosphere and demonstrating the importance of investigating species that are often overlooked [2-8].

Rodents are an important source of emerging virus infections [9] and are reservoir hosts for a wide range of viruses including coronaviruses, paramyxoviruses and picornaviruses [10-13]. The abundant and diverse virome harbored by rodents likely reflects their propensity to live in relatively large and dense populations and their speciose nature: Rodentia is the largest mammalian order, comprising 2200 species, and hence approximately $40 \%$ of all mammalian species [14,15]. Lagomorphs are closely related to rodents, although comprise only 89 extant species including rabbits and hares [16]. Recent reports have shown that rabbits and hares harbor an array of viruses such as caliciviruses, coronaviruses, bocaparvoviruses, hepatitis E and myxomavirus [17-22]. Importantly, the discovery of these novel viruses in rodents and lagomorphs has provided a more refined understanding of the evolutionary history of known pathogenic viruses, including coronaviruses, hepatitis A virus and hepaciviruses [23-27]. However, despite these recent advances, we have only scratched the surface of the potential diversity of rodent and lagomorph viruses.

In this study, we generated and investigated RNA sequencing data from European rodents and rabbits that were previously found to be positive for novel alphacoronaviruses and hantaviruses $[11,20,25,28]$. Our aim was to perform an unbiased discovery of additional viruses that were present in these samples, reveal their evolutionary history, and assess their prevalence in their host populations. Accordingly, we demonstrate the presence of novel and highly divergent RNA viruses and discuss the potential pitfalls of the use of enteric samples for virus discovery.

\section{Materials and Methods}

\subsection{Samples}

We re-analyzed two samples previously reported to harbor alphacoronaviruses $[11,20,25]$ and one sample positive for hantavirus [28]. These samples included a UK Microtus agrestis gut (UKMa1), a UK Microtus agrestis kidney (UKMa K4D) and a France-resident Oryctolagus cuniculus intestinal wash (L232) (Table 1).

Additional screening for paramyxoviruses was performed on 130 field vole kidney samples collected from two locations in the UK (Cheshire and Leicestershire (Figure 1A)) [11,28], using primers specific for the novel paramyxovirus identified in UKMa K4D. The primers were targeting the L gene F: 5'-ACTAATTACATTTACCAACAAGG-3' and R: 5'-AGTTGGTCACGTTCWATAAT- ${ }^{\prime}$ ' and generated a $245 \mathrm{bp}$ PCR product.

Moreover, screening with primers specific for the rotavirus A that was identified in the French rabbit L232 was performed on 268 rabbit intestinal wash samples collected from 10 departments of France (North-West: Finistère, Morbihan, Loire Atlantique. Centre: Creuse, Charente, Puy-de-Dôme, Deux-Sèvres, Loire and Dordogne. South-West: Pyrénées Orientales (Figure 1B)) [20]. The primers targeted the NSP4 segment F: $5^{\prime}$-TGAAGATCCAGGAATGGCGT- $3^{\prime}$ and R: 5'-ACCTGCCAACTTTAATAGCGT-3' generating a 178 bp PCR product.

All the samples used in this study were sourced from existing pest controls programs and approved by the University of Nottingham School of Veterinary Science Ethical Panel, reference numbers 1602151102 and 1786160518. 
Table 1. The samples and the corresponding viral hits including virus type, gene and size of the retrieved fragment utilized here.

\begin{tabular}{|c|c|c|c|c|c|c|c|}
\hline Sample Name & Animal Species & Organ & Origin & Virus & Gene & $\begin{array}{c}\text { Fragment Size } \\
\text { (nt) }\end{array}$ & $\begin{array}{c}\text { Accession } \\
\text { Number }\end{array}$ \\
\hline $\mathrm{UKMa1}$ & Microtus agrestis & Intestine & UK & Rotavirus A & VP1 (partial) & 2145 & MN626437 \\
\hline UKMa1 & Microtus agrestis & Intestine & UK & Rotavirus A & VP2 (partial) & 987 & MN626438 \\
\hline UKMa1 & Microtus agrestis & Intestine & UK & Rotavirus A & VP3 (partial) & 2306 & MN626439 \\
\hline UKMa1 & Microtus agrestis & Intestine & UK & Rotavirus A & VP6 (partial) & 878 & MN626440 \\
\hline UKMa1 & Microtus agrestis & Intestine & UK & Rotavirus A & NSP2 (partial) & 900 & MN626435 \\
\hline UKMa1 & Microtus agrestis & Intestine & UK & Rotavirus A & NSP3 (partial) & 349 & MN626436 \\
\hline UKMa1 & Microtus agrestis & Intestine & UK & Astrovirus & ORF1a (partial) & 1728 & MN626433 \\
\hline UKMa1 & Microtus agrestis & Intestine & UK & Astrovirus & ORF1b (partial) & 1554 & MN626434 \\
\hline UKMa1 & Microtus agrestis & Intestine & UK & Astrovirus & Capsid (partial) & 1052 & MN626432 \\
\hline UKMa K4D & Microtus agrestis & Kidney & UK & Paramyxovirus & $L($ partial $)$ & 2731 & MN626428 \\
\hline UKMa K4D & Microtus agrestis & Kidney & UK & Paramyxovirus & $H$ (partial) & 615 & MN626427 \\
\hline $\mathrm{UKM} a \mathrm{~K} 4 \mathrm{D}$ & Microtus agrestis & Kidney & UK & Paramyxovirus & $F$ (partial) & 726 & MN626426 \\
\hline UKMa K4D & Microtus agrestis & Kidney & UK & Paramyxovirus & $M$ (partial) & 760 & MN626429 \\
\hline UKM $a$ K4D & Microtus agrestis & Kidney & UK & Paramyxovirus & $P($ partial $)$ & 856 & MN626431 \\
\hline UKMa K4D & Microtus agrestis & Kidney & UK & Paramyxovirus & $N$ (partial) & 1046 & MN626430 \\
\hline L232 & Oryctolagus cuniculus & Intestinal wash & FR & Rotavirus A & $V P 1$ (partial) & 3268 & MN626420 \\
\hline $\mathrm{L} 232$ & Oryctolagus cuniculus & Intestinal wash & $\mathrm{FR}$ & Rotavirus A & VP2 (partial) & 2645 & MN626424 \\
\hline L232 & Oryctolagus cuniculus & Intestinal wash & FR & Rotavirus A & VP3 (partial) & 2536 & MN626421 \\
\hline L232 & Oryctolagus cuniculus & Intestinal wash & FR & Rotavirus A & VP6 (partial) & 1336 & MN626422 \\
\hline L232 & Oryctolagus cuniculus & Intestinal wash & FR & Rotavirus A & VP7 (partial) & 978 & MN626423 \\
\hline L232 & Oryctolagus cuniculus & Intestinal wash & FR & Rotavirus A & NSP2 (partial) & 980 & MN626417 \\
\hline $\mathrm{L} 232$ & Oryctolagus cuniculus & Intestinal wash & FR & Rotavirus A & NSP3 (partial) & 951 & MN626418 \\
\hline L232 & Oryctolagus cuniculus & Intestinal wash & FR & Rotavirus A & NSP4 (partial) & 584 & MN626419 \\
\hline L232 & Oryctolagus cuniculus & Intestinal wash & FR & Picorna-like virus & Non-structural polyprotein (partial) & 890 & MN626416 \\
\hline L232 & Oryctolagus cuniculus & Intestinal wash & FR & Picorna-like virus & Non-structural polyprotein contig 2 (partial) & 2187 & MN626416 \\
\hline L232 & Oryctolagus cuniculus & Intestinal wash & FR & Picorna-like virus & Structural polyprotein (partial) & 2349 & MN626416 \\
\hline $\mathrm{L} 232$ & Oryctolagus cuniculus & Intestinal wash & FR & Sobemovirus & Polyprotein P2ab (partial) & 1653 & MN626425 \\
\hline L232 & Oryctolagus cuniculus & Intestinal wash & FR & Luteovirus & Peptidase (partial) & 2067 & MN626414 \\
\hline L232 & Oryctolagus cuniculus & Intestinal wash & FR & Luteovirus & $R d R p$ (partial) & 1269 & MN626413 \\
\hline L232 & Oryctolagus cuniculus & Intestinal wash & FR & Luteovirus & Coat protein (partial) & 573 & MN626415 \\
\hline
\end{tabular}



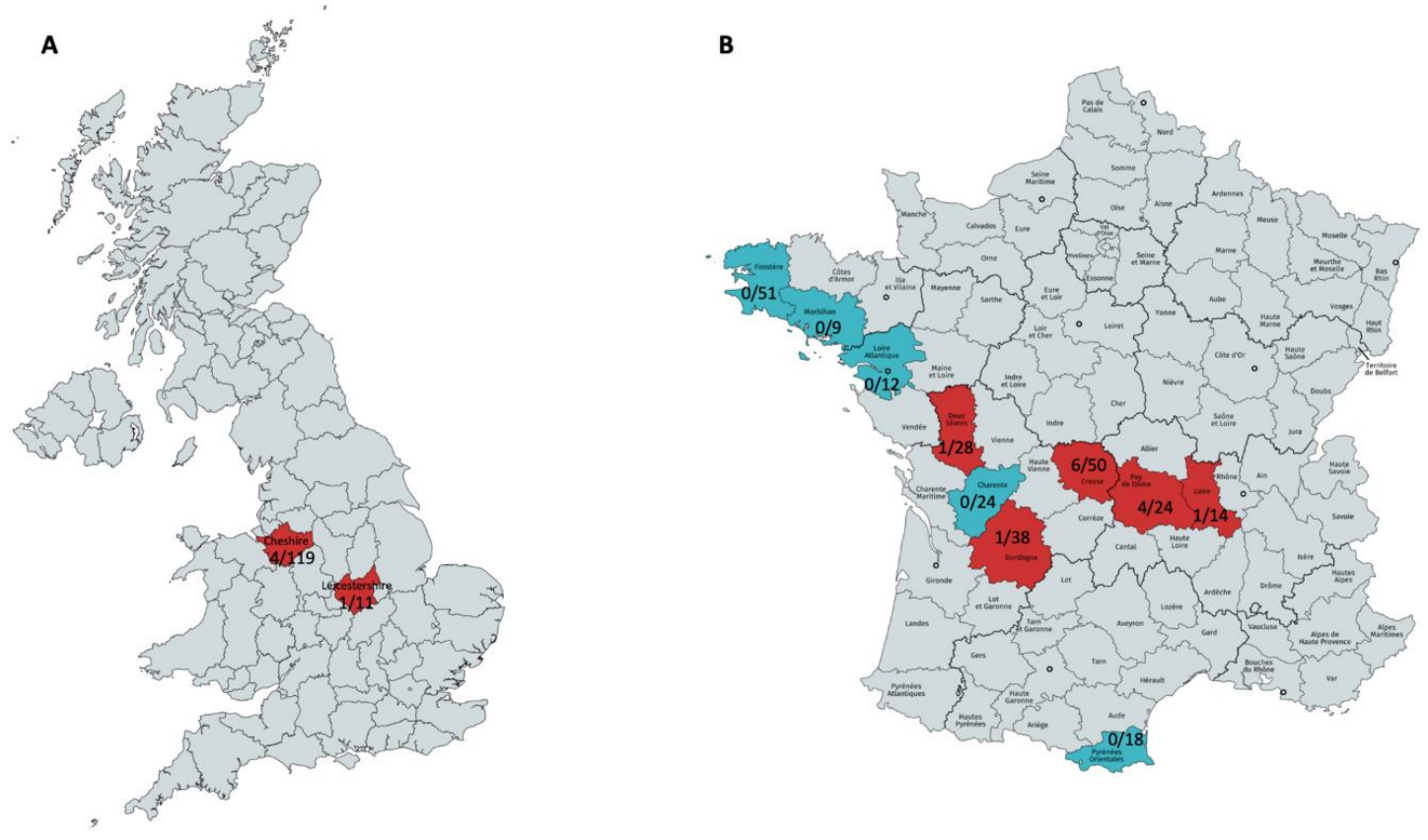

Figure 1. Maps of the UK (A) and France (B) illustrating the regions that the field vole paramyxovirus (A) and rabbit rotavirus A (B) were detected, along with their frequency. (A) Cheshire and Leicestershire (highlighted in red) had four and one positive field voles with paramyxovirus. (B) The departments Creuse, Puy-de-Dôme, Deux-Sèvres, Loire and Dordogne (highlighted in red) had six, four, one, one and one positives, respectively. The departments Charente, Finistère, Morbihan, Loire Atlantique and Pyrénées Orientales had no positives.

\subsection{Nucleic Acid Preparation}

Total RNA was extracted from $1 \mathrm{~mm}^{3}$ sections of kidney (UKMa K4D) or intestinal tissue samples (UKMa1) using the GenElute ${ }^{\mathrm{TM}}$ Mammalian Total RNA Miniprep Kit (Sigma Aldrich, Steinheim, Germany). Total RNA was extracted from intestinal fluid for the French L232 rabbit using the QIAamp Viral RNA Mini Kit (Qiagen, Hilden, Germany). The RNA to cDNA EcoDry ${ }^{\mathrm{TM}}$ Premix-Random Hexamers kit (Clontech, Saint-Germain-en-Laye, France)—was used for cDNA synthesis.

\subsection{High-Throughput Sequencing}

High-throughput sequencing was performed on total RNA extracted from all the three samples (UKMa K4D, UKMa1 and L232) using the Illumina HiSeq platform at Source Bioscience, Nottingham, UK. Genomic DNA (gDNA) was depleted using DNaseI, and ribosomal RNA (rRNA) was removed using NEBNext ${ }^{\circledR}$ rRNA Depletion Kit (Human/Mouse/Rat) with RNA Sample Purification Beads (New England Biolabs, Ipswich, MA, USA) prior to the library construction. Each read length was $2 \times 150 \mathrm{bp}$, and the insert size was $200 \mathrm{bp}$ on average. All the sequence data generated were analyzed using the Geneious Prime 2019.0.4 software. The reads were assembled into contiguous sequence (contigs) with de novo assembly performed with Geneious Prime. By using BlastX, the assembled contigs were compared against the RefSeq sequence database of all the virus proteins downloaded from GenBank. The minimum e-value was set to $1 \times 10^{-5}$ to maintain both high sensitivity and low rates of false positive hits [2]. All the contigs that matched viruses were confirmed by PCR.

\subsection{Analysis of Virus Abundance}

The number of viral reads in each data set was measured by mapping the raw total reads generated from the high-throughput sequencing to the identified viral contigs. The host ribosomal protein L4 (RPL4) gene was used as a host gene reference marker. The Oryctolagus cuniculus RPL4 gene (NM_001195817.1) was used for the rabbit, while the Microtus ochrogaster RPL4 gene (XM_005347781.3) was employed 
for the field vole. The abundance of viral reads was calculated by dividing the number of mapped reads by the total number of reads in each library. The graphs were generated with GraphPad Prism 8 (v8.1.2, GraphPad Software, San Diego, California USA).

\subsection{Contig Confirmation PCR}

Specific primers were designed for contig confirmation, and for gap-filling between contigs, based on the known sequences of the contigs. All the primers were evaluated in silico with the Primer3 online tool. The Geneious Prime software was used for mapping and annotating. PCR reactions were carried out in a PTC-200 Peltier Thermal Cycler (MJ Research, Waltham, Massachusetts, USA). The PCR reactions were performed with HotStarTaq Polymerase (Qiagen, Hilden, Germany) according to manufacturer's instructions. The PCR products were subjected to Sanger sequencing at Source Bioscience, Nottingham.

All the virus sequences generated in this study have been deposited on GenBank under the accession numbers MN626413-MN626440.

\subsection{Phylogenetic Analysis}

To facilitate phylogenetic analysis, 57 reference paramyxovirus sequences were downloaded from GenBank and the $F, H, L, M, N$ and $P$ genes extracted. Similarly, 50 rotavirus A reference sequences were downloaded for the VP1, VP2, VP3, VP6, NSP2, NSP3 segments, as were 47 reference sequences of astroviruses for ORF1a, ORF1b and capsid genes. Amino acid and nucleotide sequences were aligned using ClustalW [29] and phylogenetic analyses were performed using the maximum likelihood (ML) method within the Molecular Evolutionary Genetics Analysis version 7 (MEGA7) [30] package. Analyses of aligned amino acid sequences utilized a Jones-Taylor-Thornton (JTT) amino acid substitution model with uniform rates of variation, and complete deletion of gaps, with statistical robustness assessed using bootstrap resampling (500 pseudo-replicates). In addition, a phylogenetic analysis of nucleotide sequence data was performed using the General Time Reversible (GTR) nucleotide substitution model with a gamma distribution of rate variation, a class of invariant sites $(\Gamma+\mathrm{I})$, and complete deletion of gaps, with statistical robustness assessed using bootstrap resampling (100 pseudo-replicates). As the nucleotide-based phylogenies (Figures S1-S5) were topologically similar to those inferred using amino acid sequences only the latter are shown in the main text.

Details on the number of sequences used for the phylogenetic analysis of each gene as well as their length are given in Table 1.

\section{Results}

\subsection{Abundance of Viral Reads}

A total of 51,744,718 paired reads were generated for UKMa K4D, 63,152,134 for UKMa1, and $8,396,334$ for L232. The rabbit L232 (intestinal wash) had the highest abundance of viral reads ranging between $0.0008 \%$ and $0.19 \%$, followed by the field vole UKMa K4D (kidney) with $0.0003-0.002 \%$ and finally the field vole UKMa1 (intestine) with $0.00004-0.0002 \%$ (Figure 2A,B). The number of host RPL4 reads was proportional to the number of viral reads in each sample. The abundance of viral and RPL4 reads in each animal were correlated: the animals with the highest abundance of host reads also had the highest abundance of viral reads. A novel rotavirus A, picorna-like virus and coronavirus (previous study [20]) were identified in the rabbit, a novel paramyxovirus and hantavirus (previous study [28]) in the field vole $\mathrm{UKM} a \mathrm{~K} 4 \mathrm{D}$, and a novel astrovirus, rotavirus $\mathrm{A}$ and coronavirus (previous study $[11,25]$ ) in the field vole UKMa1 (Figure 2A,B). We now briefly describe each in turn. 


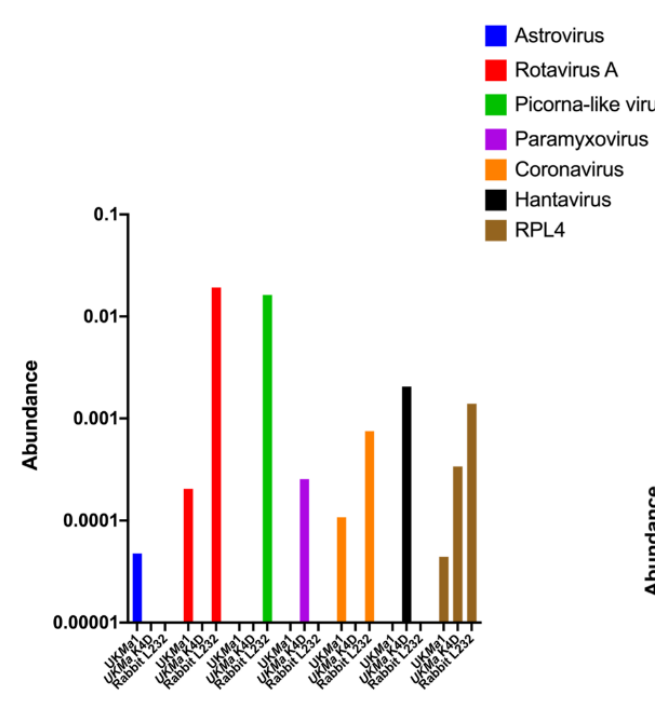

B

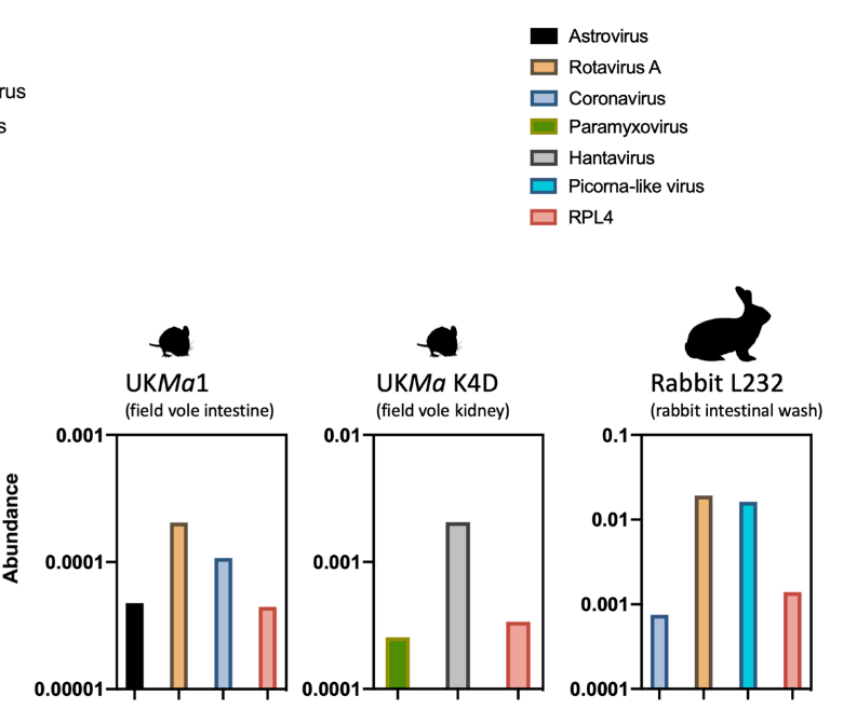

Figure 2. Overview of viral reads identified in this study. (A) Host associations (UK Microtus agrestis gut (UKMa1), UKMa K4D and rabbit L232) with the viral reads identified in this study: astrovirus, rotavirus A, picorna-like virus, paramyxovirus, coronavirus, hantavirus and host reference gene ribosomal protein L4 (RPL4). (B) Individual representation of the abundance of viral reads in each animal sample, measured as a percentage of viral reads in $\log 10$ scale.

\subsection{Paramyxovirus}

A novel narmovirus was discovered in the kidney of the UK field vole (UKMa K4D). A total of 6734 nt were retrieved for this virus, representing the $F, H, L, M, N$ and $P$ genes (Table 1 ). In terms of sequence similarity, its closest relative was Bank vole virus (MF943130), with 76\%, 61\%, 71\%, 87\%, 90\% and $62 \%$ similarity for $F, H, L, M, N$ and $P$ genes, respectively, at the amino acid level (Table 2).

To determine the evolutionary relationship of the novel UK field vole paramyxovirus to the other viruses within the family, we performed phylogenetic analyses for each of the $F, H, L, M, N$ and $P$ genes. The same phylogenetic pattern was observed in every gene, with the rodent narmoviruses comprising a distinct clade within the family with $>90 \%$ bootstrap support (Figures 3, S1 and S2). Specifically, this rodent-specific clade comprised UKMa K4D, Bank vole virus (MF943130), Mossman virus (NC005339) and Nariva virus (NC017937), and has been named narmovirus genus within the Paramyxoviridae by ICTV.

Further PCR screening on additional UK field vole samples showed $3.8 \%$ prevalence (5 positives in 130 voles tested) (Figure 1A). 
Table 2. Nucleotide and amino-acid identities of each gene/segment utilized in this study compared to the closest related viruses and the cut off for novel genotypes.

\begin{tabular}{|c|c|c|c|c|c|c|c|}
\hline Virus & Gene/Segment & Animal & GenBank acc. No & Most Closely Related Virus & $\begin{array}{c}\text { Nucleotide } \\
\text { Sequence Identity } \\
(\%)\end{array}$ & $\begin{array}{c}\text { Cut Off for } \\
\text { Genotypes (\%) * }\end{array}$ & $\begin{array}{l}\text { Assigned } \\
\text { Genotype }\end{array}$ \\
\hline \multirow{13}{*}{ Rotavirus A } & VP1 & $\begin{array}{c}\text { Rabbit } \\
\text { Field vole }\end{array}$ & $\begin{array}{l}\text { MN626420 } \\
\text { MN626437 }\end{array}$ & $\begin{array}{l}\text { Bovine rotavirus core protein } \\
\text { Human rotavirus A strain B10 }\end{array}$ & $\begin{array}{l}96.24 \\
76.96\end{array}$ & 83 & $\begin{array}{l}\mathrm{R} 2 \\
\mathrm{R}^{*}\end{array}$ \\
\hline & \multirow{2}{*}{ VP2 } & Rabbit & MN626424 & Rotavirus A giraffe/UCD/IRL/2007 & 98.38 & \multirow{2}{*}{84} & $\mathrm{C} 2$ \\
\hline & & Field vole & MN626438 & $\begin{array}{c}\text { Rotavirus A strain } \\
\text { RVA/Cow-wt/ZAF/1605/2007/G6P [5] }\end{array}$ & 78.21 & & $\mathrm{C}^{*}$ \\
\hline & \multirow{2}{*}{ VP3 } & Rabbit & MN626421 & $\begin{array}{c}\text { Rotavirus A isolate } \\
\text { RVA/Human-tc/MAR/ma31/2011/G8P [14] }\end{array}$ & 98.34 & \multirow{2}{*}{81} & M2 \\
\hline & & Field vole & MN626439 & BatRVA/KEN/BATp39/Rousettus aegyptiacus/2015 & 69.74 (in aa) & & $\mathrm{M}^{*}$ \\
\hline & \multirow{2}{*}{ VP6 } & Rabbit & MN626422 & $\begin{array}{c}\text { Rotavirus A strain RVA/roe } \\
\text { deer-wt/SLO/D38-14/2014/G6P [15] }\end{array}$ & 98.8 & \multirow{2}{*}{85} & I2 \\
\hline & & Field vole & MN626440 & Human rotavirus A isolate Omsk07-79 & 78.46 & & $\mathrm{I}^{*}$ \\
\hline & VP7 & Rabbit & MN626423 & $\begin{array}{c}\text { Rotavirus A strain } \\
\text { RVA/Sheep-tt/ESP/OVR762/2002/G8P [14] }\end{array}$ & 97.75 & 80 & G8 \\
\hline & \multirow{2}{*}{ NSP2 } & Rabbit & MN626417 & $\begin{array}{c}\text { Rotavirus A strain } \\
\text { RVA/Human-wt/ITA/111-05-27/2005/G6P [14] }\end{array}$ & 96.99 & \multirow{2}{*}{85} & N2 \\
\hline & & Field vole & MN626435 & Rotavirus A RVA/Dog-tc/JPN/RS15/1982/G3P [3] & 76.01 & & $\mathrm{~N}^{*}$ \\
\hline & \multirow[t]{2}{*}{ NSP3 } & Rabbit & MN626418 & $\begin{array}{c}\text { Rotavirus A strain } \\
\text { RVA/Human-wt/BEL/B10925/1997/G6P [14] }\end{array}$ & 98.86 & \multirow[t]{2}{*}{85} & T6 \\
\hline & & Field vole & MN626436 & $\begin{array}{l}\text { Rotavirus A RVA/Human-wt//PN/12597/2014/G8P } \\
{[14]}\end{array}$ & 76.72 (in aa) & & $\mathrm{T}^{*}$ \\
\hline & NSP4 & Rabbit & MN626419 & Rotavirus A strain dog-wt/GER/88977/2013/G8P1 & 98.43 & 85 & E2 \\
\hline \multirow{3}{*}{ Astrovirus } & ORF1a & \multirow{3}{*}{ Field vole } & MN626433 & Astrovirus Er/SZAL6/HUN/2011 & 46.3 (in aa) & - & - \\
\hline & ORF1b & & MN626434 & Astrovirus Er/SZAL6/HUN/2011 & 70 (in aa) & - & - \\
\hline & Capsid & & MN626432 & Astrovirus Er/SZAL6/HUN/2011 & 73.31 (in aa) & - & - \\
\hline \multirow{3}{*}{ Picorna-like virus } & nonstructural polyprotein & \multirow{3}{*}{ Rabbit } & MN626416 & Blackbird arilivirus & 35.57 (in aa) & - & - \\
\hline & nonstructural polyprotein & & MN626416 & Blackbird arilivirus & 48.75 (in aa) & - & - \\
\hline & structural polyprotein & & MN626416 & Blackbird arilivirus & 34.24 (in aa) & - & - \\
\hline \multirow{6}{*}{ Paramyxovirus } & $L$ & \multirow{6}{*}{ Field vole } & MN626428 & Bank vole virus & 70.66 (in aa) & - & - \\
\hline & $H$ & & MN626427 & Bank vole virus & 61.19 (in aa) & - & - \\
\hline & $F$ & & MN626426 & Bank vole virus & 76.35 (in aa) & - & - \\
\hline & M & & MN626429 & Bank vole virus & 86.96 (in aa) & - & - \\
\hline & $P$ & & MN626431 & Bank vole virus & 62.41 (in aa) & - & - \\
\hline & $N$ & & MN626430 & Bank vole virus & 89.66 (in aa) & - & - \\
\hline \multirow{3}{*}{ Luteovirus } & coat protein & \multirow{3}{*}{ Rabbit } & MN626415 & Pea enation mosaic virus 1 & 53.90 (in aa) & - & - \\
\hline & Peptidase & & MN626414 & Pea enation mosaic virus 1 & 38.88 (in aa) & - & - \\
\hline & $R d R p$ & & MN626413 & Alfalfa enamovirus 2 & 77.64 (in aa) & - & - \\
\hline
\end{tabular}

${ }^{*}$ Indicates novel unassigned genotype. 
$\mathbf{L}$

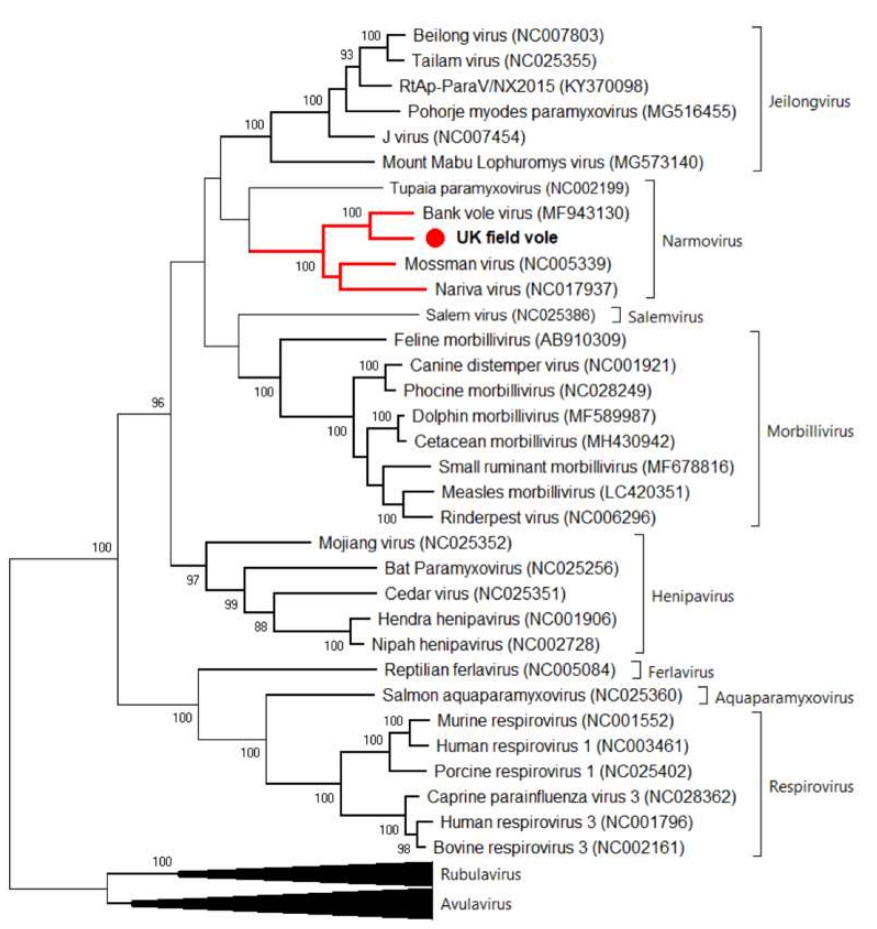

0.50

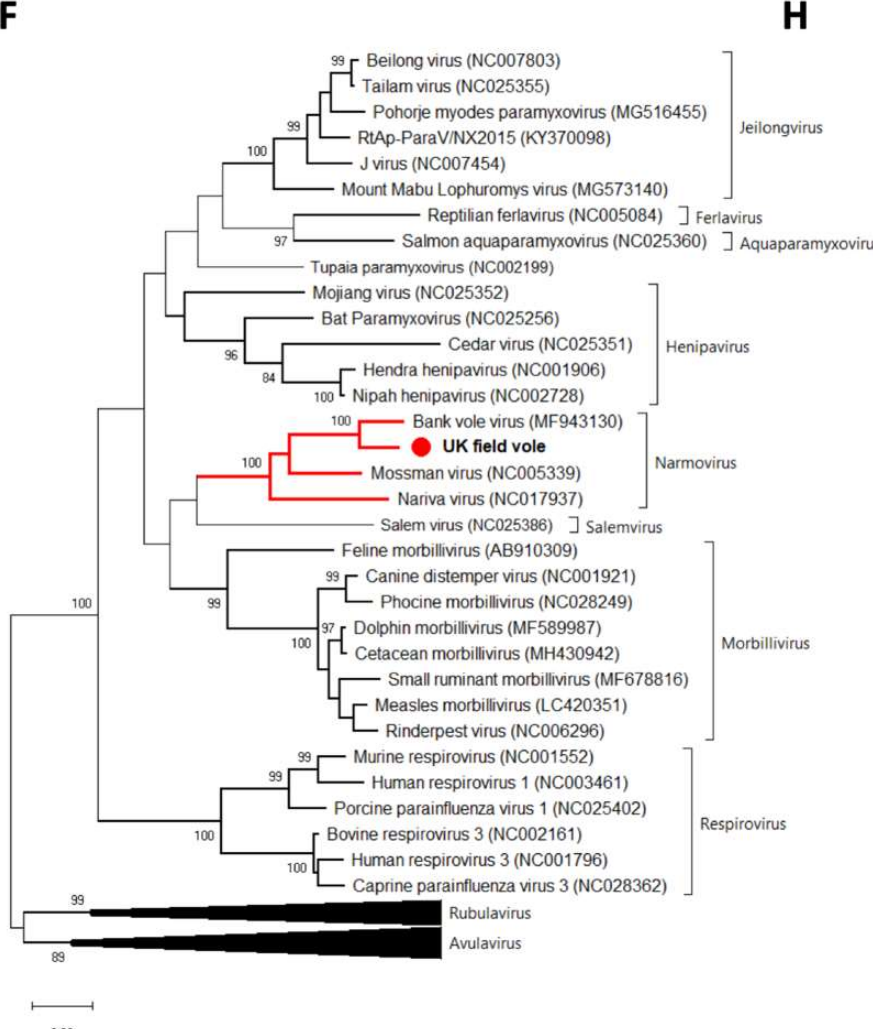

020

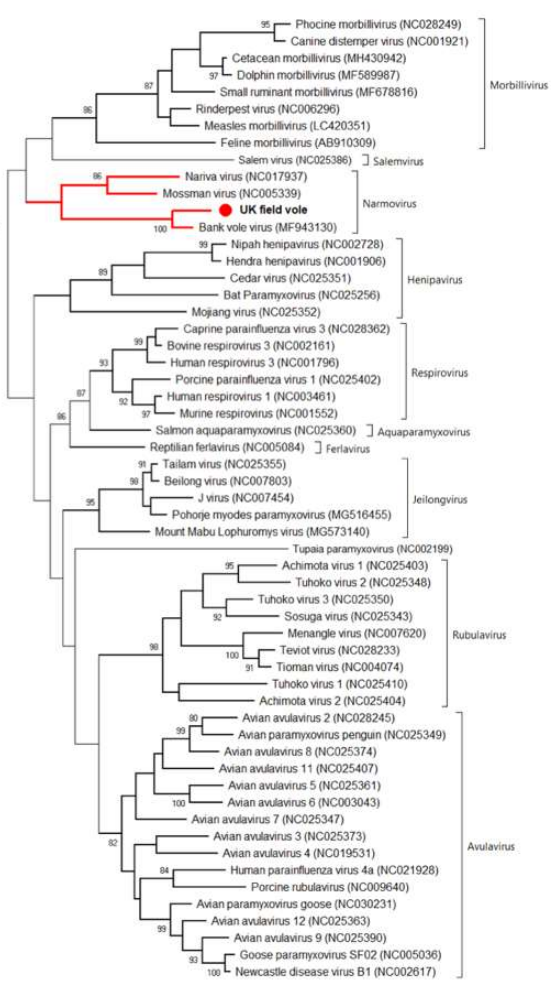

oss

Figure 3. Phylogenetic relationships of the field vole paramyxovirus based on the $L, F$ and $H$ genes. The trees represent maximum likelihood phylogenetic analyses of paramyxovirus partial L (910 aa), F (242 aa) and H (205 aa) gene sequences, revealing that the rodent narmoviruses form a single clade within the Paramyxoviridae. The novel sequence obtained from the UK field vole UKMa K4D was analyzed alongside reference sequences representing a diverse set of paramyxoviruses. Reference sequences are indicated by their GenBank accession numbers. Branch lengths are drawn to a scale of amino acid substitutions per site. Numbers above individual branches indicate bootstrap support; only values $>80 \%$ are shown. Narmoviruses are highlighted in red and the novel UK field vole paramyxovirus is marked with a red dot. For clarity, some large viral clades have been collapsed. 


\subsection{Rotavirus $A$}

Two rotaviruses A were discovered in the intestinal samples of the UK field vole (UKMa1) and the French rabbit L232. A total of $7565 \mathrm{nt}$ and 13,278 nt (Table 1) were retrieved for UKMa1 and L232, respectively. Blastn analysis of all the available rotavirus A segments (VP1, VP2, VP3, VP6, VP7, NSP2, NSP3, and NSP4) revealed that the rabbit RVA was closely related ( $>96 \%$ ) to other viruses from a range of host species including human, bovine, giraffe and roe deer (Table 2). These findings were confirmed by the phylogenetics analysis for each segment (Figure 4, Figures S3 and S4). In contrast, the field vole rotavirus A was more divergent, with nucleotide similarities of $\sim 75 \%$ to the closest relatives in the VP1, VP2, VP3, VP6, NSP2 and NSP3 segments, suggesting a novel genotype of RVA in each of the retrieved segments (Table 2). Phylogenetic analysis showed that UKMa1 RVA formed a distinct lineage within rotavirus A species, although it loosely grouped with a mouse RVA in the VP3 phylogeny (Figure 4 and Figure S3). Detailed conclusions regarding the evolutionary history of each segment of the rabbit and field vole RVA could not be drawn due to low bootstrap support on the branches of each tree. Additional PCR screening on more French rabbit intestinal washes from the same cohort revealed a $4.9 \%$ prevalence (13 positives in 268 samples). Six originated from Creuse department in central France, four from the neighboring Puy-de-Dôme department, with the other three from the departments Deux-Sèvres, Loire and Dordogne (Figure 1B). All the positive samples originated from central France with the exception of Charente, whereas no positive cases were identified in the north-west and south-west departments. However, no more positives were detected in the UK rodent cohort.

\subsection{Astrovirus}

A novel mamastrovirus was discovered in the intestine of the UK field vole (UKMa1). In total, 4334 nt were retrieved for the ORF1a, ORF1b and the capsid genes (Table 1). BlastX results revealed that the closest relative was Astrovirus Er/SZAL6/HUN/2011 from a European roller bird (Coracias garrulus). The two viruses were $46 \%, 70 \%$ and $73 \%$ similar at the amino acid level in the ORF1a, ORF1b and capsid genes, respectively (Table 2). Phylogenetic analysis of all the three genes showed that the field vole and roller viruses formed a distinct clade within the Mamastrovirus genus supported by $>90 \%$ bootstrap replicates in capsid and ORF1a (Figure 5 and Figure S5).

\subsection{Picorna-Like Virus}

Two contigs of a novel picorna-like virus were retrieved from the intestine of the French rabbit L232 with a total of $5642 \mathrm{nt}$ (4752 nt and $890 \mathrm{nt}$ ) (Table 1). A blastX analysis revealed that in the NTPase, 3C peptidase, RNA-dependent-RNA-polymerase (RdRp) and capsid proteins the novel rabbit picorna-like virus was only 44\%,52\%,61\% and 34\% similar at the amino acid level to their closest relative (Blackbird arilivirus) (NC040820) (Table 2). Phylogenetic analysis revealed that the virus clustered with the Blackbird arilivirus with 100\% bootstrap support (Figure 6). Surprisingly, both viruses clustered within the invertebrate picorna-like viruses, suggesting that they might have in fact been derived from a dietary component. 


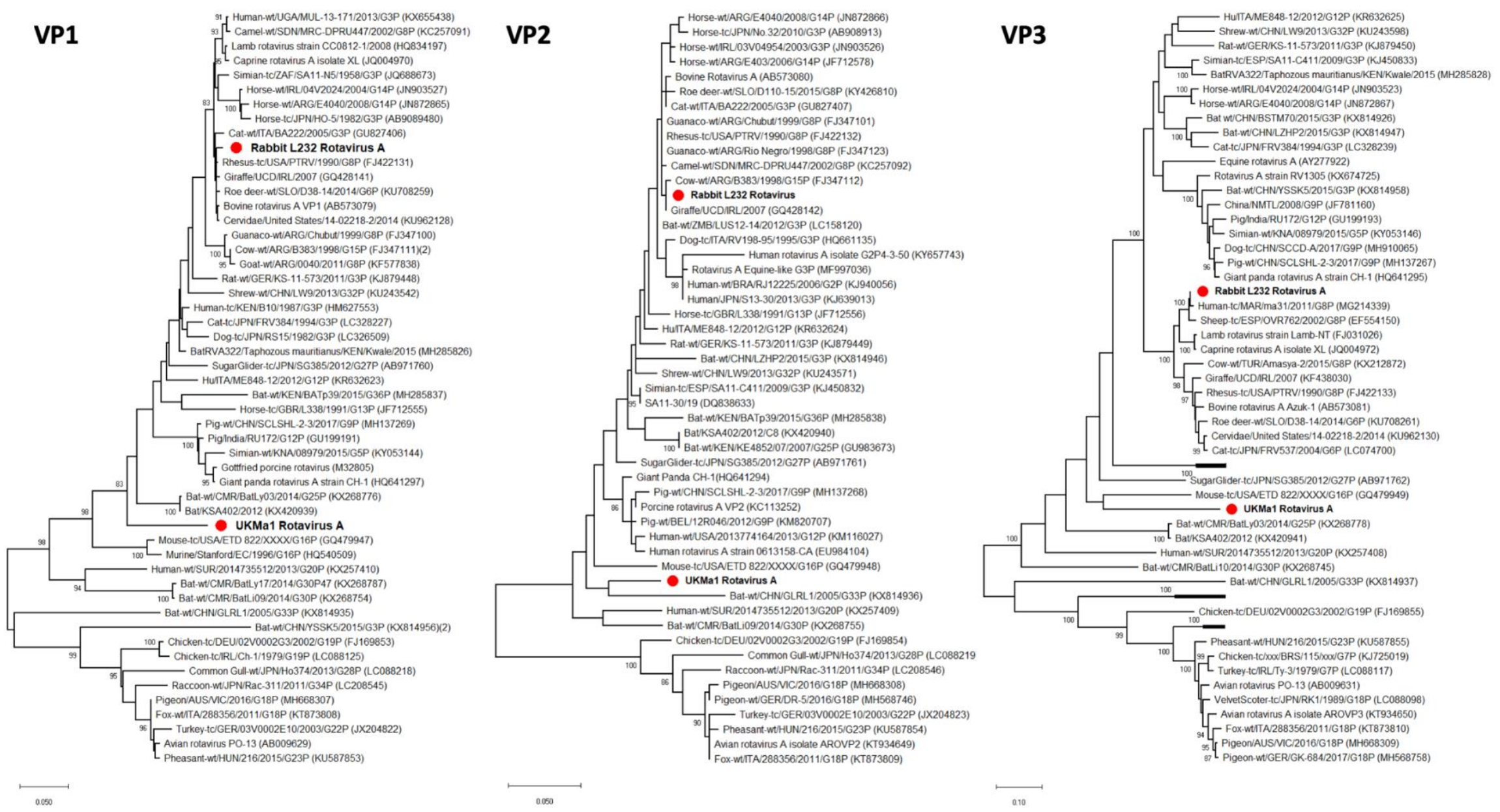

Figure 4. Phylogenetic relationships of the field vole and the rabbit rotavirus A based on the VP1, VP2 and VP3 segment. The trees represent maximum likelihood phylogenetic analyses of rotavirus A partial VP1 (648 aa), VP2 (329 aa) and VP3 (791 aa) segment sequences. The novel sequences obtained from the UK field vole UKMa1 and the French rabbit L232 were analyzed alongside reference sequences representing rotaviruses A from different host species. Reference sequences are indicated by their GenBank accession numbers. Branch lengths are drawn to a scale of amino acid substitutions per site. Numbers above individual branches indicate bootstrap support; only values $>80 \%$ are shown. The novel rotaviruses A are marked with a red dot. For clarity, some viral clades have been collapsed. 


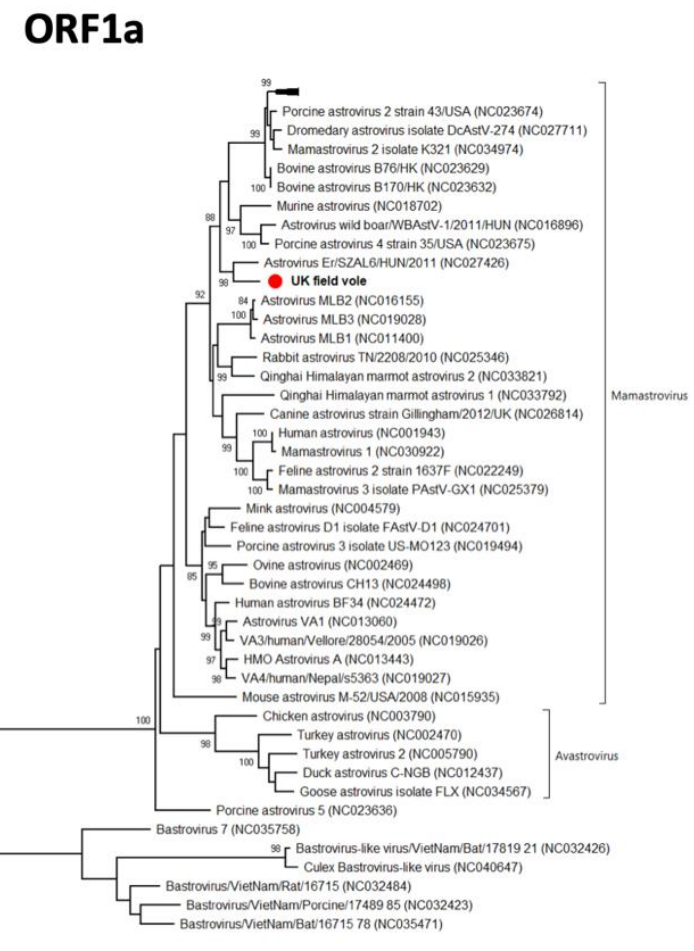

ORF1b

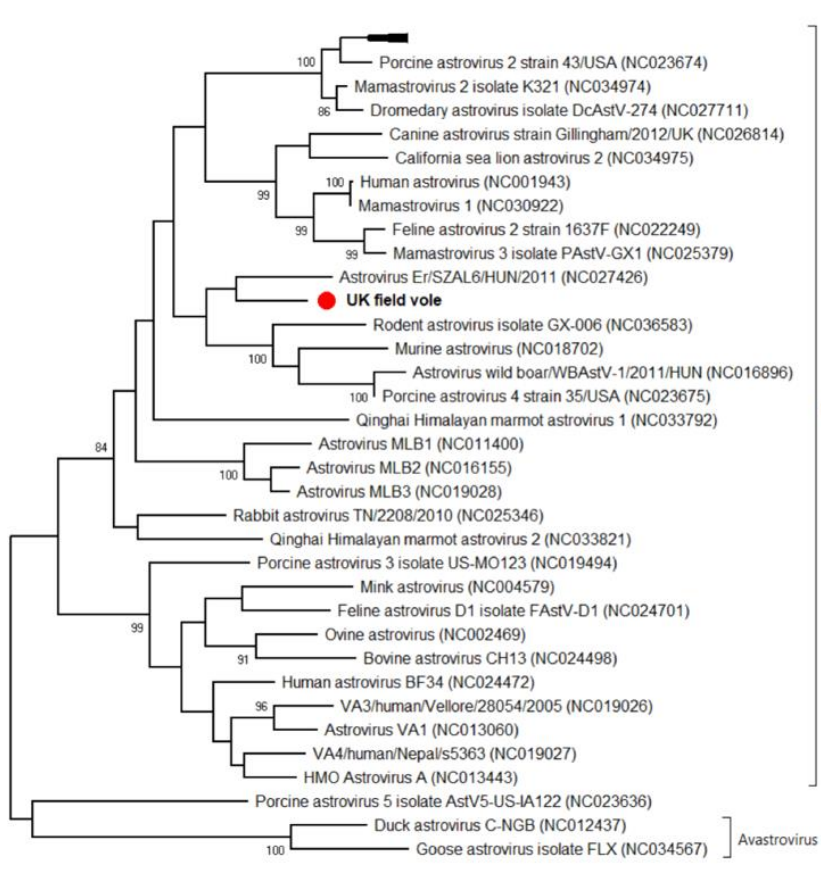

Capsid
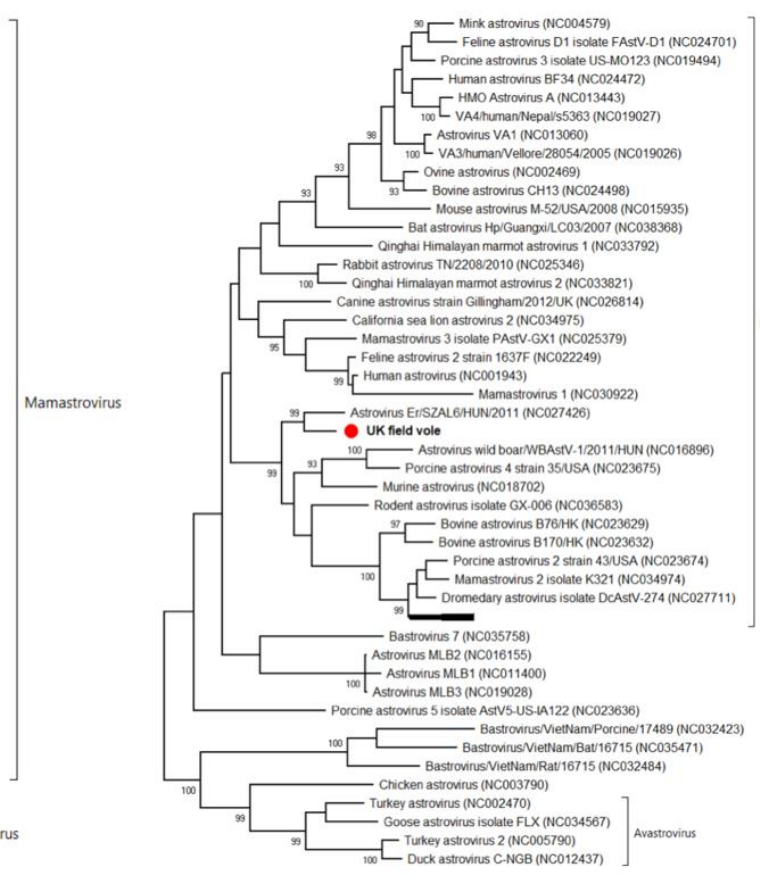

202

5. Phylogenetic relationships of the novel field vole astrovirus based on the ORF1a, ORF1b and capsid genes. The trees represent maximum likelihood phylogenetic analyses of astrovirus partial ORF1a (508 aa), ORF1b (298 aa) and capsid (350 aa) gene sequences. The novel sequence obtained from the UK field vole UKMa1 was analyzed alongside reference sequences representing all different genera of astroviruses. Reference sequences are indicated by their GenBank accession numbers. Branch lengths are drawn to a scale of amino acid substitutions per site. Numbers above individual branches indicate the bootstrap support; only values $>80 \%$ are shown. The novel UKMa1 astrovirus is marked with a red dot. For clarity, some viral clades have been collapsed. 
RdRp

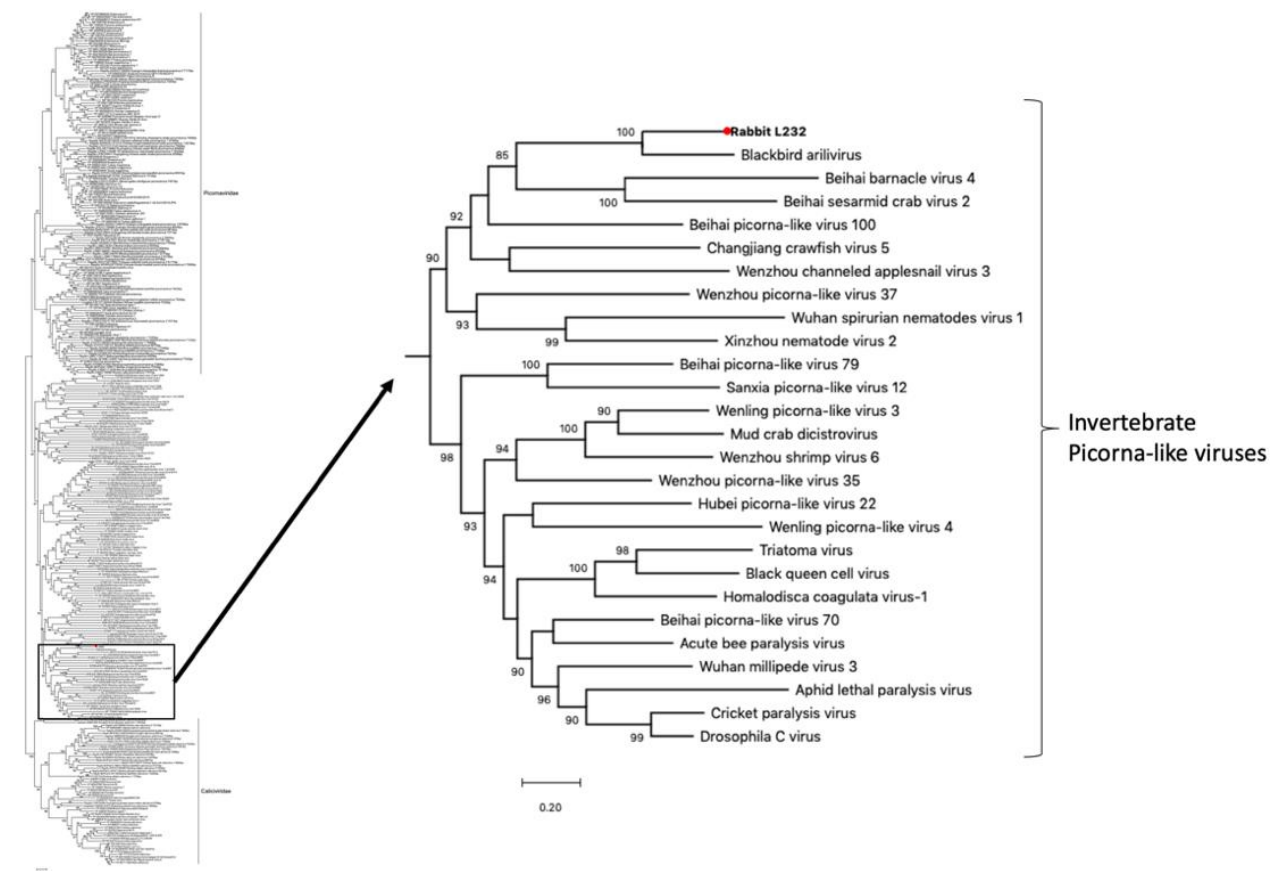

Figure 6. Phylogenetic relationships of the novel rabbit picorna-like virus based on analyses of the $R d R p$ gene. Maximum likelihood phylogenetic analysis of picornavirus partial $R d R p$ gene sequences, revealing that the rabbit picorna-like virus falls within a clade of invertebrate picorna-like viruses. The novel sequence obtained from the French rabbit L232 was analyzed alongside reference sequences representing different picorna-like viruses. Branch lengths are drawn to a scale of amino acid substitutions per site. Numbers above individual branches indicate the bootstrap support; only values $>80 \%$ are shown. The novel rabbit L232 associated picorna-like virus is marked with a red dot.

\subsection{Plant Viruses}

In addition to the vertebrate and invertebrate viruses described above, two likely plant viruses were detected in the intestinal wash of the French rabbit: a sobemovirus and a luteovirus. A $1653 \mathrm{nt}$ contig was retrieved for the sobemovirus, encompassing polyprotein P2ab (Table 1). The polyprotein P2ab was both $98 \%$ similar to the closest relative, Cocksfoot mottle virus, at the amino acid level.

Three contigs with a total of $3909 \mathrm{nt}$ were recovered for the novel luteovirus. They contained a peptidase, RdRp, coat protein (Table 1) that were $~ 39 \%, 78$ and $54 \%$ similar, respectively, to their closest relative at the amino acid level (Table 2).

\section{Discussion}

Metagenomic next-generation sequencing enables the unbiased discovery of viruses within samples that would otherwise be missed with conventional methods targeted to specific viruses. Using this approach, we report the discovery of a novel field vole paramyxovirus (UKMa K4D) and a novel rabbit rotavirus A (L232). We also identifed a novel astrovirus, rotavirus A, in a field vole (UKMa1) and a picorna-like virus in a rabbit (L232). While unbiased metagenomics is capable of identifying novel viral species, it is noticeable that only a small proportion of the total number of reads corresponded to viral reads, confirming previous observations [31]. An obvious limitation of metagenomics in detecting viral genomes is the requirement for a sufficient number of viral reads within a library to detect a virus and construct complete virus genomes, which is itself dependent on the RNA quality within a sample [32]. Comparison of virus abundance in each animal revealed an association between number of viral/host reads and sample quality, with rabbit L232 being the best quality sample. The difference between the quality of the rabbit and the field vole samples is likely due to the method of collection; the 
rabbit was euthanized and immediately processed [20], whereas the field voles were a result of routine pest control, and there was a delay between time of death and collection and sample preservation [11].

This study presents the first evidence of a narmovirus in European field voles. In every gene analyzed this virus clustered with narmoviruses that had been isolated from a range of rodents from diverse locations globally. Specifically, other viruses within this clade were identified in bank voles from Russia [33], wild rats in Australia [34] and common cane mice in Trinidad [35]. Such a phylogenetic pattern suggests that rodent narmoviruses are temporally and spatially widespread and arose from a single common ancestor, although this will need to be confirmed with a larger sample of viruses. We previously observed a similar pattern of shared ancestry for rodent alphacoronaviruses [25].

Phylogenetic analysis of the rabbit rotavirus A revealed both high sequence similarity $(>96 \%)$ and clustering with rotavirus A sequences sampled from different mammalian species. However, the lack of a several reference sequences for all the segments analyzed, together with the ability of rotaviruses A to reassort [36], makes it difficult to draw any detailed conclusions about the origin of these viruses. In contrast, the rotavirus A identified in the UK field vole was considerably more divergent phylogenetically, falling in a more basal position, although with some similarity to another rodent rotavirus. In addition, the closest relatives only exhibited $\sim 75 \%$ sequence similarity (Table 2 ), thus fulfilling the criteria for a novel rotavirus A genotype in each segment [37], and perhaps indicating the presence of another rodent-specific virus lineage.

Although next-generation metagenomic sequencing has fundamentally changed virus discovery, many viruses still lack information about their host species [38] and the interpretation of results is greatly complicated by commonplace reagent contamination [39]. It is therefore important to confirm any metagenomic findings by PCR on the original samples. In addition, depending on the tissue, it may be difficult to determine the exact virus host (i.e., intestinal tissue sample) due to 'contamination' from the diet of the animal. Indeed, previous studies have shown the detection of viruses in gut and fecal samples of humans and animals that are likely derived from their diet [40-42]. Due to their detection in multiple animals we are confident that the field vole and the rabbit were the likely hosts for the paramyxovirus and the rotavirus A, respectively. However, it has not been determined whether the field vole is the true host of the rotavirus and astrovirus detected. The field vole-related astrovirus clustered with an astrovirus detected in fecal samples of European rollers (Coracias garrulus) in Hungary [43]. This bird species is found in a wide variety of habitats and is known to feed on insects and small vertebrates, including rodents [44]. However, as noted by the original authors, this virus shared a common ancestor with rodent-borne astroviruses so it is possible that it has a dietary origin since European rollers prey on small rodents [44]. Hence, the clade comprising UKM $a 1$ and Er/SZAL6/HUN/2011 astrovirus may in reality represent a rodent clade of mamastroviruses. This will require confirmation through the analysis of additional rodent astroviruses.

Another example of probable dietary contamination was the detection of the novel picorna-like virus and the plant viruses in the rabbit intestinal sample. According to our phylogenetic analysis, the host of the picorna-like virus was likely an invertebrate because it closely grouped with other invertebrate picorna-like viruses such as Beihai barnacle virus 4 (NC032446) and Beihai sesarmid crab virus 2 (NC032641). Dietary contamination was also the likely explanation for Blackbird arilivirus (NC040820) discovered in a metagenomic analysis of a mixed pool obtained from brain, lung and intestine tissues [45]. While the original authors suggested that the virus might have a plant origin, our phylogenetic indicates that both viruses in fact likely have an invertebrate host.

In sum, our results confirm that metagenomic next-generation sequencing is capable of discovering previously unknown and divergent RNA viruses. However, our data also highlight that definitive identification of the likely host species can be complicated because of dietary or environmental contamination. As a consequence, true assignment of host species requires wider prevalence studies together analysis of multiple tissue types.

Supplementary Materials: The following are available online at http://www.mdpi.com/1999-4915/12/1/47/s1, Figure S1: Phylogenetic relationships of the field vole paramyxovirus based on the $L, F$ and $H$ genes., Figure S2: 
Phylogenetic relationships of the field vole paramyxovirus based on the $M, N$ and $P$ genes, Figure S3: Phylogenetic relationships of the field vole and the rabbit rotavirus A based on the VP1, VP2 and VP3 segments, Figure S4: Phylogenetic relationships of the field vole and the rabbit rotavirus A based on the VP6, VP7 and NSP2 segments, Figure S5: Phylogenetic relationships of the novel field vole astrovirus based on the ORF1a, ORF1b and capsid genes.

Author Contributions: T.T., C.P.M. and J.K.B. conceived and designed the experiments; T.T., J.G.C., C.P.M., E.M.-L. and G.U. performed the experiments; E.M.-L., G.U., R.E.T. and M.B. provided samples; T.T., M.S., E.C.H. and J.K.B. analyzed the data. T.T., E.C.H. and J.K.B. wrote the paper; all authors edited the final draft. All authors have read and agreed to the published version of the manuscript.

Funding: This study was supported by the Biotechnology and Biological Sciences Research Council [grant number BB/J014508/1]. ECH is supported by an ARC Australian Laureate Fellowship (FL170100022).

Conflicts of Interest: The authors declare no conflict of interest.

\section{References}

1. Koonin, E.V.; Senkevich, T.G.; Dolja, V.V. The ancient Virus World and evolution of cells. Biol. Direct 2006, 1, 29. [CrossRef]

2. Shi, M.; Lin, X.D.; Tian, J.H.; Chen, L.J.; Chen, X.; Li, C.X.; Qin, X.D.; Jun, L.; Cao, J.P.; Eden, J.S.; et al. Redefining the invertebrate RNA virosphere. Nature 2016, 540, 539. [CrossRef]

3. Shi, M.; Lin, X.D.; Chen, X.; Tian, J.H.; Chen, L.J.; Li, K.; Wang, W.; Eden, J.S.; Shen, J.J.; Liu, L.; et al. The evolutionary history of vertebrate RNA viruses. Nature 2018, 556, 197-202. [CrossRef] [PubMed]

4. Lauber, C.; Seitz, S.; Mattei, S.; Suh, A.; Beck, J.; Herstein, J.; Börold, J.; Salzburger, W.; Kaderali1, L.; Briggs, J.A.G.; et al. Deciphering the Origin and Evolution of Hepatitis B Viruses by Means of a Family of Non-enveloped Fish. Viruses. Cell Host Microbe 2017, 22, 387-399. [CrossRef] [PubMed]

5. Li, C.X.; Shi, M.; Tian, J.H.; Lin, X.D.; Kang, Y.J.; Chen, L.J.; Qin, X.C.; Xu, J.; Holmes, E.C.; Zhang, Y.Z. Unprecedented genomic diversity of RNA viruses in arthropods reveals the ancestry of negative-sense RNA viruses. eLife 2015, 4, e05378. [CrossRef] [PubMed]

6. Webster, C.L.; Waldron, F.M.; Robertson, S.; Crowson, D.; Ferrari, G.; Quintana, J.F.; Brouqui, J.M.; Bayne, E.H.; Longdon, B.; Buck, A.H.; et al. The Discovery, Distribution, and Evolution of Viruses Associated with Drosophila melanogaster. PLoS Biol. 2015, 13, e1002210. [CrossRef]

7. Wille, M.; Netter, H.; Littlejohn, M.; Yuen, L.; Shi, M.; Eden, J.S.; Klaassen, M.; Holmes, E.C.; Hurt, A.C. A Divergent Hepatitis D-Like Agent in Birds. Viruses 2018, 10, 720. [CrossRef]

8. Shi, M.; Lin, X.D.; Vasilakis, N.; Tian, J.H.; Li, C.X.; Chen, L.J.; Eastwood, G.; Diao, X.N.; Chen, M.H.; Chen, X.; et al. Divergent Viruses Discovered in Arthropods and Vertebrates Revise the Evolutionary History of the Flaviviridae and Related Viruses. J. Virol. 2016, 90, 659-669. [CrossRef]

9. Luis, A.D.; Hayman, D.T.; O'Shea, T.J.; Cryan, P.M.; Gilbert, A.T.; Pulliam, J.R.; Mills, J.N.; Timonin, M.E.; Willis, C.K.; Cunningham, A.A.; et al. A comparison of bats and rodents as reservoirs of zoonotic viruses: Are bats special? Proc. Biol. Sci. 2013, 280, 20122753. [CrossRef]

10. Wu, Z.; Lu, L.; Du, J.; Yang, L.; Ren, X.; Liu, B.; Jiang, J.; Yang, J.; Dong, J.; Sun, L.; et al. Comparative analysis of rodent and small mammal viromes to better understand the wildlife origin of emerging infectious diseases. Microbiome 2018, 6, 178. [CrossRef]

11. Tsoleridis, T.; Onianwa, O.; Horncastle, E.; Dayman, E.; Zhu, M.; Danjittrong, T.; WachtL, M.; Behnke, J.M.; Chapman, S.; Strong, V.; et al. Discovery of Novel Alphacoronaviruses in European Rodents and Shrews. Viruses 2016, 84, 24. [CrossRef] [PubMed]

12. Firth, C.; Bhat, M.; Firth, M.A.; Williams, S.H.; Frye, M.J.; Simmonds, P.; Conte, J.M.; Ng, J.; Garcia, J.; Bhuva, N.P.; et al. Detection of zoonotic pathogens and characterization of novel viruses carried by commensal Rattus norvegicus in New York City. MBio 2014, 5, e01933-14. [CrossRef] [PubMed]

13. Sachsenröder, J.; Braun, A.; Machnowska, P.; Ng, T.F.F.; Deng, X.; Guenther, S.; Bernstein, S.; Ulrich, R.G.; Delwart, E.; Johne, R. Metagenomic identification of novel enteric viruses in urban wild rats and genome characterization of a group A rotavirus. J. Gen. Virol. 2014, 95, 2734-2747. [CrossRef] [PubMed]

14. Huchon, D.; Madsen, O.; Sibbald, M.J.; Ament, K.; Stanhope, M.J.; Catzeflis, F.; de Jong, W.W.; Douzery, E.J. Rodent phylogeny and a timescale for the evolution of Glires: Evidence from an extensive taxon sampling using three nuclear genes. Mol. Biol. Evol. 2002, 19, 1053-1065. [CrossRef] [PubMed]

15. Phan, T.G.; Kapusinszky, B.; Wang, C.; Rose, R.K.; Lipton, H.L.; Delwart, E.L. The fecal viral flora of wild rodents. PLoS Pathog 2011, 7, e1002218. [CrossRef] 
16. Ge, D.; Wen, Z.; Xia, L.; Zhang, Z.; Erbajeva, M.; Huang, C.; Yang, Q. Evolutionary history of lagomorphs in response to global environmental change. PLoS ONE 2013, 8, e59668. [CrossRef]

17. Mahar, J.E.; Hall, R.N.; Shi, M.; Mourant, R.; Huang, N.; Strive, T.; Holmes, E.C. The discovery of three new hare lagoviruses reveals unexplored viral diversity in this genus. Virus. Evol. 2019, 5, vez005. [CrossRef]

18. Nicholson, L.J.; Mahar, J.E.; Strive, T.; Zheng, T.; Holmes, E.C.; Ward, V.K.; Duckworth, J.A. Benign Rabbit Calicivirus in New Zealand. Appl. Environ. Microbiol. 2017, 83, e00090-17. [CrossRef]

19. Lanave, G.; Martella, V.; Farkas, S.L.; Fehér, S.M.; Bodnar, L.; Lavazza, A.; Decaro, N.; Buonavoglia, C.; Bányai, K. Novel bocaparvoviruses in rabbits. Vet. J. 2015, 206, 131-135. [CrossRef]

20. Monchatre-Leroy, E.; Boué, F.; Boucher, J.M.; Renault, C.; Moutou, F.; Ar Gouilh, M.; Umhang, G. Identification of Alpha and Beta Coronavirus in Wildlife Species in France: Bats, Rodents, Rabbits, and Hedgehogs. Viruses 2017, 9, 364. [CrossRef]

21. Corman, V.M.; Hilgensloh, L.; Voigt, U.; Marklewitz, M.; Siebert, U.; Drosten, C.; Drexler, J.F. Hepatitis E Virus Infection in European Brown Hares, Germany, 2007-2014. Emerg. Infect. Dis. 2019, 25, 1233-1235. [CrossRef]

22. Kerr, P.J.; Eden, Jo.; di Giallonardo, F.; Peacock, D.; Liu, J.; Strive, T.; Read, A.F.; Holmes, E.C. Punctuated Evolution of Myxoma Virus: Rapid and Disjunct Evolution of a Recent Viral Lineage in Australia. J. Virol. 2019, 93, e01994-18. [CrossRef]

23. Lau, S.K.P.; Woo, P.C.Y.; Li, K.S.M.; Tsang, A.K.L.; Fan, R.Y.Y.; Luk, H.K.H.; Cai, Ji.; Chan, Kw.; Zheng, Bo.; Wang, M.; et al. Discovery of a novel coronavirus, China Rattus coronavirus HKU24, from Norway rats supports the murine origin of Betacoronavirus 1 and has implications for the ancestor of Betacoronavirus lineage A. J. Virol. 2015, 89, 3076-3092. [CrossRef]

24. Wang, W.; Lin, X.D.; Guo, W.P.; Zhou, R.H.; Wang, M.R.; Wang, C.Q.; Ge, S.; Mei, S.H.; Li, M.H.; Shi, M.; et al. Discovery, diversity and evolution of novel coronaviruses sampled from rodents in China. Virology 2015, 474, 19-27. [CrossRef]

25. Tsoleridis, T.; Chappell, J.G.; Onianwa, O.; Marston, D.A.; Fooks, A.R.; Monchatre-Leroy, E.; Umhang, G.; Müller, M.A.; Drexler, J.F.; Drosten, C.; et al. Shared Common Ancestry of Rodent Alphacoronaviruses Sampled Globally. Viruses 2019, 11, 125. [CrossRef]

26. Drexler, J.F.; Corman, V.M.; Lukashev, A.N.; van den Brand, J.M.A.; Gmyl, A.P.; Brünink, S.; Rasche, A.; Seggewi $\beta$, N.; Feng, H.; Leijten, L.M.; et al. Evolutionary origins of hepatitis A virus in small mammals. Proc. Natl. Acad. Sci. USA 2015, 112, 15190-15195. [CrossRef]

27. Drexler, J.F.; Corman, V.M.; Müller, M.A.; Lukashev, A.N.; Gmyl, A.; Coutard, B.; Adam, A.; Ritz, D.; Leijten, L.M.; van Riel, D.; et al. Evidence for novel hepaciviruses in rodents. PLoS Pathog. 2013, 9, e1003438. [CrossRef]

28. Chappell, J.G.; Tsoleridis, T.; Onianwa, O.; Drake, G.; Ashpole, I.; Dobbs, P.; Edema, W.; Kumi-Ansah, F.; Bennett, P.; Tarlinton, R.E.; et al. Retrieval of the Complete Coding Sequence of the UK-Endemic Tatenale Orthohantavirus Reveals Extensive Strain Variation and Supports its Classification as a Novel Species. bioRxiv 2019. [CrossRef]

29. Thompson, D.J.; Higgins, D.G.; Gibson, T.J. CLUSTAL W: Improving the sensitivity of progressive multiple sequence alignment through sequence weighting, position-specific gap penalties and weight matrix choice. Nucleic. Acids Res. 1994, 22, 4673-4680. [CrossRef]

30. Kumar, S.; Stecher, G.; Tamura, K. MEGA7: Molecular Evolutionary Genetics Analysis Version 7.0 for Bigger Datasets. Mol. Biol. Evol. 2016, 33, 1870-1874. [CrossRef]

31. Wille, M.; Shi, M.; Klaassen, M.; Hurt, A.C.; Holmes, E.C. Virome heterogeneity and connectivity in waterfowl and shorebird communities. ISME J. 2019, 13, 2603-2616. [CrossRef]

32. Zhang, Y.Z.; Chen, Y.M.; Wang, W.; Qin, X.C.; Holmes, E.C. Expanding the RNA Virosphere by Unbiased Metagenomics. Annu. Rev. Virol. 2019, 6, 119-139. [CrossRef]

33. Alkhovsky, S.; Butenko, A.; Eremyan, A.; Shchetinin, A. Genetic characterization of bank vole virus (BaVV), a new paramyxovirus isolated from kidneys of bank voles in Russia. Arch. Virol. 2018, 163, 755-759. [CrossRef]

34. Miller, P.J.; Boyle, D.B.; Eaton, B.T.; Wang, L. F. Full-length genome sequence of Mossman virus, a novel paramyxovirus isolated from rodents in Australia. Virology 2003, 317, 330-344. [CrossRef]

35. Lambeth, L.S.; Yu, M.; Anderson, D.E.; Crameri, G.; Eaton, B.T.; Wang, L.F. Complete genome sequence of Nariva virus, a rodent paramyxovirus. Arch. Virol. 2009, 154, 199-207. [CrossRef] 
36. McDonald, S.M.; Nelson, M.I.; Turner, P.E.; Patton, J.T. Reassortment in segmented RNA viruses: Mechanisms and outcomes. Nat. Rev. Microbiol. 2016, 14, 448-460. [CrossRef]

37. Matthijnssens, J.; Ciarlet, M.; Rahman, M.; Attoui, H.; Bányai, K.; Estes, M.K.; Gentsch, J.R.; Iturriza-Gómara, M.; Kirkwood, C.D.; Martella, V.; et al. Recommendations for the classification of group A rotaviruses using all 11 genomic RNA segments. Arch Virol 2008, 153, 1621-1629. [CrossRef]

38. Simmonds, P.; Adams, M.J.; Benkő, M.; Breitbart, M.; Brister, J.R.; Carstens, E.B.; Davison, A.J.; Delwart, E.; Gorbalenya, A.E.; Harrach, B.; et al. Virus taxonomy in the age of metagenomics. Nat. Rev. Microbiol. 2017, 15, 161. [CrossRef]

39. Holmes, E.C. Reagent contamination in viromics: All that glitters is not gold. Clin. Microbiol. Infect. 2019, 25, 1167-1168. [CrossRef]

40. Chong, R.; Shi, M.; Grueber, C.E.; Holmes, E.C.; Hogg, C.J.; Belov, K.; Barrs, V.R. Fecal Viral Diversity of Captive and Wild Tasmanian Devils Characterized Using Virion-Enriched Metagenomics and Metatranscriptomics. J. Virol. 2019, 93, e00205-e00219. [CrossRef]

41. Wang, Y.; Yang, S.; Liu, D.; Zhou, C.; Li, W.; Lin, Y.; Wang, X.; Shen, Q.; Wang, H.; Li, C.; et al. The fecal virome of red-crowned cranes. Arch. Virol. 2019, 164, 3-16. [CrossRef]

42. Siqueira, J.D.; Dominguez-Bello, M.G.; Contreras, M.; Lander, O.; Caballero-Arias, H.; Xutao, D.; Noya-Alarcon, O.; Delwart, E. Complex. virome in feces from Amerindian children in isolated Amazonian villages. Nat. Commun. 2018, 9, 4270. [CrossRef]

43. Pankovics, P.; Boros, Á.; Kiss, T.; Delwart, E.; Reuter, G. Detection of a mammalian-like astrovirus in bird, European roller (Coracias garrulus). Infect. Genet. Evol. 2015, 34, 114-121. [CrossRef]

44. Kiss, O.; Elek, Z.; Moskát, C. High. breeding performance of European Rollers Coracias garrulus in heterogeneous farmland habitat in southern Hungary. Bird Study 2014, 61, 496-505. [CrossRef]

45. Van Borm, S.; Steensels, M.; Mathijs, E.; Yinda, C.K.; Matthijnssens, J.; Lambrecht, B. Complete coding sequence of a novel picorna-like virus in a blackbird infected with Usutu virus. Arch. Virol. 2018, 163, 1701-1703. [CrossRef]

(C) 2019 by the authors. Licensee MDPI, Basel, Switzerland. This article is an open access article distributed under the terms and conditions of the Creative Commons Attribution (CC BY) license (http://creativecommons.org/licenses/by/4.0/). 